\title{
Efficacy of Fentanyl and/or Lidocaine on Total Antioxidants and Total Oxidants During Craniotomy
}

\author{
Ayse Mizrak, MD; Ibrahim Erkutlu, MD; Mehmet Alptekin, MD; Elzem Sen, MD; \\ Murat Geyik, MD; Abdulvahab Gok, MD; and Unsal Oner, MD
}

\begin{abstract}
Objective: The aim of this study was to investigate the oxidative, hemodynamic, and analgesic effects of local lidocaine infiltration, or intravenous (IV) fentanyl injection, or a combination of lidocaine and IV fentanyl during head fixation in a 3-pin headrest in patients undergoing elective craniotomy.

Design: Double-blind, randomized, placebo-controlled study.

Setting: Gaziantep University Medical Faculty, Department of Anesthesiology and Reanimation.

Methods: Eighty patients were randomly assigned to one of four groups. Five minutes before pin fixation, patients in group $L$ received I $\mathrm{mg} / \mathrm{kg}$ of lidocaine $2 \%$ for scalp infiltration $(\mathrm{n}=20)$, group $\mathrm{F}$ received I $\mu \mathrm{g} / \mathrm{kg}$ of IV fentanyl $(\mathrm{n}=20$ ), group $\mathrm{FL}$ received I mg/kg of lidocaine $2 \%$ and I $\mu \mathrm{g} / \mathrm{kg}$ of fentanyl $(n=20)$, and group $P$ received a placebo $(n=20)$. Following standard anesthesia, basal, pre- and post-fixational hemodynamic data were recorded. Blood samples were taken for evaluation of oxidant and antioxidant levels before and after pin fixation.

Results: The total antioxidant levels after pin fixation were highest in group FL followed by group F, then group $L$ and finally group $P$ (ie, $F L>F>L>P)(P<0.05)$. The mean arterial blood pressure (MAP) after pin fixation was higher than the MAP before pin fixation in groups $L$ and $P(P<0.05)$, but was lower in groups $\mathrm{F}$ and $\mathrm{FL}(P<0.05)$.

Conclusion: The combination of fentanyl and lidocaine before pin fixation is useful in preventing severe hemodynamic response to pain stimuli, such as pin fixation, and in increasing total antioxidant levels in the post-fixational period during craniotomy in adults.
\end{abstract}

Keywords: Craniotomy; Hemodynamic variables; Pin fixation; Total antioxidant status; Total oxidant status

$\mathrm{S}$ -pin insertion is an essential maneuver commonly used to stabilize the head during neurosurgery. Pain is elicited when scalp and periosteal nerve endings are stimulated during pin fixation and skin incision, as occurs during craniotomy, ${ }^{1}$ and although there is an adequate level of anesthesia, the skull-pins that penetrate the scalp may cause sudden hemodynamic changes. In specific patient groups, such as those who have intracerebral vascular problems (eg, aneurysms or arteriovenous malformations), an increase in blood pressure may be harmful. ${ }^{2-4}$ Furthermore, in patients with impaired cerebral auto-regulation, this may result in a sudden increase in cerebral blood flow and volume that precipitates intracranial hypertension..$^{2-5}$ Insertion of skull-pins is a strong nociceptive stimulus even under deep anesthesia. ${ }^{6}$ Stress is defined as a condition in an organism that results from the action of one or more stressors that may be of either external or internal origin; therefore, pin fixation may be accepted as a stress factor. 
It is well known that intensive stress response results in the creation of reactive oxygen species (ROS) such as hydrogen peroxide $\left(\mathrm{H}_{2} \mathrm{O}_{2}\right)$, hydroxyl radical $\left(\mathrm{HO}^{-}\right)$, and superoxide anion radicals that cause lipid peroxidation, especially in membranes that may play an important role in tissue injury. ${ }^{7}$ The membrane injury causes disruption of the tissue integrity. ${ }^{8,9}$ Voronych et $\mathrm{al}^{10}$ reported that the oxidant/ antioxidant balance was disturbed in favor of activation of free radical processes, with maximal changes in the brain, after immobilization stress and emotional pain stress. Under some conditions, the increase in oxidants and decrease in antioxidants cannot be prevented, and the oxidative/ antioxidative balance shifts toward the oxidative status. Oxidative stress develops oxidized molecules (total oxidant status [TOS]) that generally form new radicals leading to radical chain reactions, or which are neutralized by antioxidants. Antioxidant molecules prevent and/or inhibit these harmful reactions and protect the organism against the toxic effects of these oxidized molecules. ${ }^{11}$ Because the measurement of individual serum antioxidants is timeconsuming, expensive, and requires complicated techniques, total antioxidant response (TAR) of a sample is measured, and is termed "total antioxidant capacity". ${ }^{12}$ Adequate intracellular levels of antioxidants are essential for the survival and health of organisms. ${ }^{13-15}$

Neurosurgical anesthesiologists are responsible for providing harmless and optimal anesthesia while maintaining a stable arterial pressure and heart rate in order to avoid dangerous complications such as hemorrhage and elevated intracranial pressure. Simple infiltration of the pin insertion area with local anesthetic or administration of intravenous (IV) fentanyl just before skull-pin insertion ${ }^{16}$ is an accepted method of preventing and attenuating hemodynamic and stress responses. ${ }^{17}$ This placebo-controlled study was intended to compare cardiovascular responses and their effect on oxidant/ antioxidant balance when skull-pins are inserted after scalp block with lidocaine $2 \%$ and/or IV fentanyl in patients undergoing craniotomy under general anesthesia.

\section{Methods}

The work presented here was performed in accordance with the most recent version of the Helsinki Declaration. This research was planned as a prospective, randomized, placebocontrolled study. After obtaining the approval of the Institutional Ethics Committee at Gaziantep University (Turkey), 80 adult patients (American Society of Anesthesiologists [ASA] physical status I and II) of either sex, undergoing elective craniotomy for resection of tumor were enrolled in the study after obtaining verbal and written informed consent. Patients were enrolled from September 2008 through March 2009.

The exclusion criteria included patients with a history of systemic hypertension, bradycardia, cardiovascular disease, beta-blocker use, any drug allergies, ophthalmic disease, chronic smoking, morbid obesity, and chronic obstructive lung disease. Elective craniotomy included the excision of space-occupying lesions in patients who had no history of pain or previous operation. These subjects were randomly allocated to treatment type. In the operating room, standard monitoring (Datex-Engstrom AS/3, Datex Medical Instrumentation Corp, Helsinki, Finland) was performed with electrocardiography, insertion of arterial catheter (for continuous blood pressure monitoring and blood sampling), pulse oximetry, and end-tidal carbon dioxide measurement. The transducer was calibrated at the level of the fourth intercostal space in the midaxillary line. Urinary bladder catheterization was performed. No patient was premedicated with any drug. After pre-oxygenation for three to five minutes with $100 \%$ oxygen, anesthesia was induced with $2 \mu \mathrm{g} / \mathrm{kg} \mathrm{IV}$ fentanyl, $2.5 \mathrm{mg} / \mathrm{kg}$ propofol and $0.1 \mathrm{mg} / \mathrm{kg}$ vecuronium and maintained with $0.75 \%$ to $1.5 \%$ isoflurane in a $50: 50$ air/ oxygen mixture. Ventilation was controlled mechanically in order to achieve an end-tidal carbon dioxide level between 28 $\mathrm{mmHg}$ and $32 \mathrm{mmHg}$. Before induction, heart rate and mean arterial pressure (MAP) were measured and recorded as baseline values. The hemodynamic variables were recorded at five minute intervals throughout the intraoperative period. Following standard anesthesia technique, pre-fixational blood samples were taken for TOS and total antioxidant status (TAS) evaluation. For each patient, two syringes (total volume $=10 \mathrm{~mL}$ ) for scalp infiltration and IV administration were prepared and numbered by an assistant blinded to the randomization. The control group (group $\mathrm{P} ; \mathrm{n}=20$ ) received no drugs; isoflurane and/or supplemental fentanyl were used to prevent excessive hemodynamic response. The lidocaine group (group $\mathrm{L} ; \mathrm{n}=20$ ) received $1 \mathrm{mg} / \mathrm{kg}$ of lidocaine $2 \%{ }^{18}$ (Jetocaine simlex ampule; Adeka Pharmaceutical Company, Istanbul, Turkey) for scalp infiltration and IV placebo $(5 \mathrm{~mL}$ of normal saline). The fentanyl group (group $\mathrm{F} ; \mathrm{n}=20$ ) received $1 \mu \mathrm{g} / \mathrm{kg}$ of IV fentanyl (fentanyl, fentanyl citrate [Abbott Laboratories, Abbott Park, Illinois, USA] $50 \mu \mathrm{g} / \mathrm{mL}$ ampul) and $5 \mathrm{~mL}$ of placebo for scalp infiltration. The fentanyl-lidocaine group (group FL; $\mathrm{n}=20$ ) received $1 \mathrm{mg} / \mathrm{kg}$ lidocaine $2 \%$ and $1 \mu \mathrm{g} / \mathrm{kg}$ IV fentanyl ${ }^{16}$ five minutes before pin fixation. Lidocaine was given through the full thickness of the scalp where the pin would be inserted, and after a two minute waiting period, $1 \mu \mathrm{g} / \mathrm{kg}$ IV fentanyl was given. ${ }^{19}$ After one minute of administering fentanyl, the Mayfield 2000 head fixator (OMI, Schaerer Mayfield USA, Inc., Cincinnati, Ohio) was placed. Five minutes after pin insertion, the arterial blood samples were taken again for TAS and TOS evaluation. The blood samples obtained were collected into heparinized tubes, and serum and plasma were separated from cells by centrifugation at $1500 \mathrm{~g}$ for 10 minutes. The serum samples were then analysed with special kits. Free sulfhydryl groups of serum samples were assayed according to the method of Ellman $^{20}$ as modified by $\mathrm{Hu}$ et al. ${ }^{21}$ Serum albumin, total protein, uric acid, total bilirubin, as well as TOS and TAS were measured using commercially available kits (Abbott Laboratories) using an automated analyzer aeroset (Abbott Laboratories). ${ }^{22}$ A Cecil 3000 spectrophotometer with a temperature controlled cuvette holder (Cecil Instruments, 


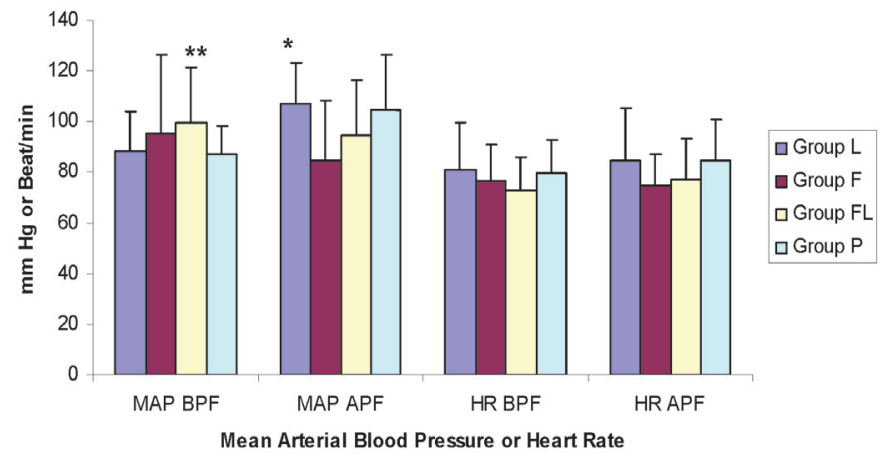

Figure 1. The mean arterial blood pressure and heart rate of the groups before and after pin fixation $(n=20$; mean $\pm S D)$. MAP BPF = mean arterial blood pressure before pin fixation; MAP APF = mean arterial blood pressure after pin fixation; HR BPF: heart rate before pin fixation; $H R$ APF = heart rate after pin fixation. ${ }^{*} P<0.05$ when comparing the MAP BPF with the MAP APF in group $L .{ }^{\star *} P<0.05$ when comparing the MAP APF with the MAP BPF in group FL.

Inc., Cambridge, England) was used. The total antioxidant status of the plasma (serum antioxidant vitamins A, E, and C, selenium [Se], ferric reducing/antioxidant power test [FRAP], thiol/albumin ratio) and malondialdehyde (MDA) ${ }^{23}$ were measured using a novel automated colorimetric measurement method for the TAR developed by Erel. ${ }^{11}$ All the evaluations and recordings were performed by an observer who was blinded to the study.

\section{Statistical Analysis}

The statistical evaluation was done using the "Statistical Package for Social Sciences (SPSS) for Windows Release 15.0". Data were expressed as means \pm standard deviation (SD), or as the number of patients. A $P$ value of $<0.05$ was considered significant. The relationship between the patient characteristic data, nominal, and ordinal variables (ASA physical status, and demographic data) were analysed using Kruskal-Wallis analysis of variance test. The intraoperative hemodynamic data, TAS and TOS values were evaluated by one-way analysis of variance (ANOVA). The MAP, heart rate, and TAS and TOS values before and after pin fixation were compared using paired sample $t$ test. We did not calculate the $\mathrm{G}$ power. However, for purposes of the power calculation, a $25 \%$ increase in TOS after pin insertion was considered to be significant.

\section{Results}

The demographic characteristics (gender, age, body mass index, and ASA physical status) and duration of surgery were similar among the groups (table 1). The TAS after pin fixation in groups $\mathrm{L}, \mathrm{F}$, and $\mathrm{P}$ were significantly lower than in group FL $(P<0.05)$. After pin fixation, TAS levels were highest in group FL, followed by group F, then group L, and lastly, group $\mathrm{P}$ (ie, $\mathrm{FL}>\mathrm{F}>\mathrm{L}>\mathrm{P})(P<0.05)$ (table 2$)$.

The MAP before pin fixation in group $\mathrm{L}$ and group $\mathrm{P}$ were significantly lower than the MAP after pin fixation $(P<0.05)$. However, the MAP after pin fixation in group FL was significantly lower than the MAP before pin fixation $(P<0.05)$. The MAP in group FL was lower than in groups L, P after pin fixation. The heart rate among the groups was similar during the intraoperative period (figure 1).

\section{Discussion}

This study demonstrates that the use of both fentanyl and lidocaine before pin fixation was more effective than local anesthetic infiltration or IV fentanyl administration alone in controlling hemodynamic responses to skull-pin holder application for craniotomies. As a result of this, both fentanyl and lidocaine use before pin fixation caused an increase in TAS and a decrease in TOS in the post-fixational period.

Intracranial surgical procedures are facilitated by rigid immobilization of the patient's head. Immobilization eliminates the potentially dangerous movement of anatomic structures during brain dissection, as well as smaller movements that are undesirable while performing microsurgery under the operating microscope. Rigid immobilization of the head is generally achieved by pin fixation attached to the headrest. ${ }^{4}$ Insertion of skull-pins into the periosteum induces not only a hemodynamic response but also an increase in stress hormones. ${ }^{17}$ This pain can be prevented if sufficiently large areas of the scalp are properly anesthetized before pin fixation by blockade of the regional nerves responsible for pain sensation. Anti-hypertensive agents (eg, clonidine), ${ }^{24,25}$ esmolol, ketamine, ${ }^{5}$ opioids (eg, fentanyl, alfentanil, sufentanil), ${ }^{26}$ and local infiltration (eg, bupivacaine, lidocaine $)^{27}$ have been used alone or in combination to suppress the hemodynamic response to skull-pin insertion. These measures sometimes cause undesired hypotension. ${ }^{28}$ Opioid analgesics are widely used in neuroanesthesia because

Table 1. Demographic data and duration of surgery of the groups.

\begin{tabular}{|c|c|c|c|c|}
\hline & $\begin{array}{c}\text { Group } L(n=20) \\
\text { mean } \pm S D\end{array}$ & $\begin{array}{c}\text { Group } F(n=20) \\
\text { mean } \pm S D\end{array}$ & $\begin{array}{c}\text { Group FL }(n=20) \\
\text { mean } \pm S D\end{array}$ & $\begin{array}{c}\text { Group } P(n=20) \\
\text { mean } \pm S D\end{array}$ \\
\hline Gender (M/F) & $11 / 9$ & $9 / 11$ & $10 / 10$ & $10 / 10$ \\
\hline Age (years) & $45.9 \pm 6.9$ & $48.5 \pm 9.0$ & $49.5 \pm 8.6$ & $50.0 \pm 8.7$ \\
\hline $\begin{array}{l}\text { Body Mass Index } \\
\qquad\left(\mathrm{kg} / \mathrm{m}^{2}\right)\end{array}$ & $25.6 \pm 4.5$ & $24.7 \pm 4.2$ & $25.4 \pm 3.2$ & $26.1 \pm 4.1$ \\
\hline $\begin{array}{l}\text { Duration of Surgery } \\
\text { (minutes) }\end{array}$ & $243.7 \pm 62.3$ & $260.2 \pm 54.7$ & $256.2 \pm 48.6$ & $260.2 \pm 55.8$ \\
\hline
\end{tabular}

Group L, lidocaine; Group F, fentanyl; Group FL, fentanyl+lidocaine; Group P, placebo. $\mathrm{SD}$, standard deviation.

$84 \quad$ Fentanyl and/or lidocaine use during craniotomy 
Table 2. The TOS and TAS values before and after pin fixation of head.

\begin{tabular}{|c|c|c|c|c|c|}
\hline Pin fixation stage & $\begin{array}{c}\text { Group } L(n=20) \\
\text { mean } \pm S D\end{array}$ & $\begin{array}{c}\text { Group } F(n=20) \\
\text { mean } \pm S D\end{array}$ & $\begin{array}{c}\text { Group FL }(n=20) \\
\text { mean } \pm S D\end{array}$ & $\begin{array}{c}\text { Group } P(n=20) \\
\text { mean } \pm S D\end{array}$ & $P$ value \\
\hline \multicolumn{6}{|l|}{ TAS } \\
\hline before & $0.8 \pm 0.6$ & $0.8 \pm 0.7$ & $0.8 \pm 0.4$ & $0.8 \pm 0.5$ & NS \\
\hline after & $0.7 \pm 0.3$ & $0.7 \pm 0.4$ & $0.9 \pm 0.4^{*}$ & $0.7 \pm 0.1$ & 0.03 \\
\hline \multicolumn{6}{|l|}{ TOS } \\
\hline before & $8.6 \pm 6.2$ & $11.8 \pm 9.5$ & $11.9 \pm 10.2$ & $8.6 \pm 3.0$ & NS \\
\hline after & $9.1 \pm 8.3$ & $9.2 \pm 2.8$ & $10.5 \pm 8.4$ & $9.2 \pm 3.7$ & NS \\
\hline $\begin{array}{l}\text { Group L, lidocaine; Grour } \\
\text { SD, standard deviation; } T \\
{ }^{*} P<0.05 \text { when comparing }\end{array}$ & $\begin{array}{l}\text { nyl; Group FL, fentan } \\
\text { l oxidant status; TAS, } \\
\text { after pin fixation in } 9\end{array}$ & $\begin{array}{l}\text { caine; Group P, place } \\
\text { ntioxidant status; NS } \\
\text { with the groups L, }\end{array}$ & gnificant. & & \\
\hline
\end{tabular}

they provide a stable heart rate and blood pressure in the face of surgical stimuli ${ }^{27}$ without causing a severe change in the cerebrospinal fluid pressure and cerebral perfusion. ${ }^{26,29,30}$ The undesired effects of opioids may be modified by atropine and phenylephrine; however, narcotics alone are not sufficient to prevent a hemodynamic response to skull-pin head holder placement. Rubial ${ }^{31}$ showed that local anesthetic infiltration at the pin sites was more effective than IV fentanyl $3 \mu \mathrm{g} / \mathrm{kg}$ to $5 \mu \mathrm{g} / \mathrm{kg}$. Similarly, Ozkose et $\mathrm{al}^{27}$ determined that IV fentanyl alone did not prevent a hemodynamic response. Similar to that study, in our study, under invasive monitoring, we administered $1 \mu \mathrm{g} / \mathrm{kg}$ IV fentanyl and $/$ or $1 \mathrm{mg} / \mathrm{kg}$ lidocaine $2 \%$ for scalp infiltration before skull-pin insertion. The MAP after pin fixation in group $\mathrm{P}$ was significantly higher than the MAP before pin fixation. Neither fentanyl nor lidocaine alone could effectively suppress the MAP. However, the combined use of both drugs was able to suppress the MAP after pin fixation. The intraoperative heart rate among the groups was similar during the same end-tidal anesthetic agent concentration, and sufficient analgesia, constituted by both fentanyl and lidocaine, may have been the reason for this result. In previous studies, local scalp infiltration and regional blocks have been used to suppress the hemodynamic response. ${ }^{2,4}$ Similar to the present study, Ozkose et $\mathrm{al}^{27}$ concluded that IV fentanyl with local infiltration of plain lidocaine into the periosteum was effective in reducing the hemodynamic response to skull-pin head holder placement in patients undergoing craniotomy. ${ }^{2,27}$

At the same time, head fixation in neurosurgical procedures may result in creation of reactive oxygen species (ROS) that cause lipid peroxidation. ${ }^{7}$ Oxygen species are key participants in damage caused by neurodegenerative processes, viral infections, cancer, and both infarction and brain edema. Therefore, tissues must be protected from this oxidative injury by expression of stress-response genes and genes encoding antioxidant enzymes, and activation of other related transcriptional regulatory proteins. This shows the importance of the TOS and TAS defense system in maintaining normal cellular physiology, facing diseases, and promoting immunity. ${ }^{32,33}$ We also thought that an imbalance of the oxidative/antioxidative status leads to an oxidative injury. Hydroxyl radical $\left(\mathrm{OH}^{-}\right)$and its subsequent radicals are the most harmful ROS (also, TOS), mainly responsible for the oxidative injury of biomolecules. ${ }^{11}$

The TAS after pin fixation in groups $\mathrm{P}, \mathrm{F}$, and $\mathrm{L}$ was significantly lower than in group FL. By using IV fentanyl with local infiltration of plain lidocaine into the periosteum, we were able to reduce the hemodynamic response and increase the antioxidant agents after the skull-pin head holder placement in patients undergoing craniotomy. Oxidized molecules generally form new radicals leading to radical chain reactions. Antioxidant molecules neutralize these reactions preventing and inhibiting these harmful reactions. ${ }^{34}$

Low levels of TOS are important in many biochemical processes, including intracellular messaging in cell differentiation, cell progression or the arrest of growth, apoptosis, immunity, and defense against micro-organisms. ${ }^{35}$ In contrast, high doses and/or inadequate removal of TOS results in oxidative stress, which may cause severe metabolic malfunction and damage to biological macromolecules. ${ }^{36}$ Increased lipid peroxidation and decreased antioxidant protection $^{37}$ may lead to cytotoxicity, mutagenicity, and carcinogenicity, depending on the properties of the epoxide in question, ${ }^{38}$ by causing DNA damage and directly inhibiting $\mathrm{Na}^{+} / \mathrm{K}^{+}$ATPases and glutamate transporters. ${ }^{39}$ The skull-pins that penetrate the skin and periosteum can easily be the gateway to infection by communicating with the external skin layer. ${ }^{40}$ Often, these complications are severe enough to necessitate interruption of treatment due to the spread of infection from the pin tracts causing osteomyelitis. ${ }^{40,41}$ In addition to the analgesic and anesthetic effects of local anesthetics, they also have bactericidal and bacteriostatic effects. ${ }^{42}$ Johnson et $\mathrm{al}^{43}$ reported that the antimicrobial capacity of bupivacaine and lidocaine are significantly greater than that of ropivacaine.

In conclusion, the use of fentanyl together with local infiltration of a lidocaine $2 \%$ scalp block before head pin fixation blunts the stress responses and sudden hemodynamic changes resulting from head pinning, and increases TAS during craniotomy in adults. Therefore, this analgesic combination should be considered in conjunction with general anesthesia for craniotomy. 


\section{References}

1. Bloomfield EL, Schubert A, Secic M, Barnett G, Shutway F, Ebrahim ZY. The influence of scalp infiltration with bupivacaine on hemodynamics and postoperative pain in adult patients undergoing craniotomy. Anesth Analg 1998;87:579-582.

2. Pinosky ML, Fishman RL, Reeves ST, Harvey SC, Patel S, Palesch Y, Dorman BH. The effect of bupivacaine skull block on the hemodynamic response to craniotomy. Anesth Analg 1996;83:1256-1261.

3. Biswas BK, Bithal PK. Preincision 0.25\% bupivacaine scalp infiltration and postcraniotomy pain: a randomized doubleblind, placebo-controlled study. J Neurosurg Anesthesiol 2003; 15:234-239.

4. Levin R, Hesselvik JF, Kourtopoulos H, Vavruch L. Local anesthesia prevents hypertension following application of the Mayfield skull-pin head holder. Acta Anaesthesiol Scand 1989;33:277-279.

5. Agarwal A, Sinha PK, Pandey CM, Gaur A, Pandey CK, Kaushik S. Effect of a subanesthetic dose of intravenous ketamine and/or local anesthetic infiltration on hemodynamic responses to skull-pin placement: a prospective, placebocontrolled, randomized, double-blind study. J Neurosurg Anesthesiol 2001;13:189-194.

6. Hillman DR, Rung GW, Thompson WR, Davis NJ. The effect of bupivacaine scalp infiltration on the hemodynamic response to craniotomy under general anesthesia. Anesthesiology 1987;67:1001-1003.

7. Kovács P, Juránek I, Stankovicová T, Svec P. Lipid peroxidation during acute stress. Pharmazie 1996;51:51-53.

8. Bagchi D, Carryl OR, Tran MX, Bagchi M, Garg A, Milnes MM, Williams CB, Balmoori J, Bagchi DJ, Mitra S, Stohs SJ. Acute and chronic stress-induced oxidative gastrointestinal mucosal injury in rats and protection by bismuth subsalicylate. Mol Cell Biochem 1999;196:109-116.

9. Cochrane CG. Mechanisms of oxidant injury of cells. Mol Aspects Med 1991;12:137-147.

10. Voronych NM, Iemel'ianenko IV. [Lipid peroxidation and antioxidant system activity in the brain, stomach and heart tissues and blood serum of rats under stress]. Fiziol $\mathrm{Zh}$ 1994;40:114-117.

11. Erel O. A novel automated method to measure total antioxidant response against potent free radical reactions. Clin Biochem 2004;37:112-119.

12. Miller NJ, Rice-Evans C, Davies MJ, Gopinathan V, Milner A A novel method for measuring antioxidant capacity and its application to monitoring the antioxidant status in premature neonates. Clin Sci (Lond) 1993;84:407-412.

13. Aleryani S, Milo E, Rose Y, Kostka P. Superoxide-mediated decomposition of biological S-nitrosothiols. J Biol Chem 1998;273:6041-6045.

14. Brouwer M, Brouwer TH. Biochemical defense mechanisms against copper-induced oxidative damage in the blue crab, Callinectes sapidus. Arch Biochem Biophys 1998;351: 257-264.

15. Grazioli V, Schiavo R, Casari E, Marzatico F, Rodriguez y Baena R, Gaetani P. Antioxidant enzymatic activities and lipid peroxidation in cultured human chondrocytes from vertebral plate cartilage. FEBS Lett 1998;431:149-153.

16. Yildiz K, Madenoglu H, Dogru K, Kotanoglu MS, Akin A, Boyaci A. The effects of intravenous fentanyl and intravenous fentanyl combined with bupivacaine infiltration on the hemodynamic response to skull-pin insertion. J Neurosurg Anesthesiol 2005;17:9-12.

17. Geze S, Yilmaz AA, Tuzuner F. The effect of scalp block and local infiltration on the hemodynamic and stress response to skull-pin placement for craniotomy. Eur J Anaesthesiol 2009;26:298-303.
18. Bithal PK, Pandia MP, Chaturvedi A, Radhakrishnan M, Prabhakar H, Sharma D. Lidocaine infiltration of the scalp does not completely abolish increased intraocular pressure due to skull pin insertion. J Clin Neurosci 2006;13:730-732.

19. Dahlgren N, Messeter K. Treatment of stress response to laryngoscopy and intubation with fentanyl. Anesthesia 1981;36:1022-1026.

20. Ellman GL. Tissue sulfhydryl groups. Arch Biochem Biophys 1959;82:70-77.

21. Hu ML, Louie S, Cross CE, Motchnik P, Halliwell B. Antioxidant protection against hypochlorous acid in human plasma. J Lab Clin Med 1993;121:257-262.

22. Erel O. A novel automated direct measurement method for total antioxidant capacity using a new generation, more stable ABTS radical cation. Clin Biochem 2004;37:277-285.

23. Góralska J, Hartwich J, Siedlecka D, Gruca A, Dolecki M, Drozdz W, Trzos M, Dembinska-Kiec A. Bioavailability of antioxidant vitamins. Relation between the modality of intake and plasma markers of oxidative stress. Genes Nutr 2007;2:147-149.

24. Costello TG, Cormack JR. Clonidine premedication decreases hemodynamic responses to pin head-holder application during craniotomy. Anesth Analg 1998;86:1001-1004.

25. Jellish WS, Theard MA, Cheng MA, Leonetti JP, Crowder CM, Tempelhoff $\mathrm{R}$. The effects of clonidine premedication and scalp infiltration of lidocaine on hemodynamic responses to laryngoscopy and skull pin head-holder insertion during skull base procedures. Skull Base 2001;11:169-176.

26. Jamali S, Archer D, Ravussin P, Bonnafous M, David P, Ecoffey C. The effect of skull-pin insertion on cerebrospinal fluid pressure and cerebral perfusion pressure: influence of sufentanil and fentanyl. Anesth Analg 1997;84:1292-1296.

27. Ozköse Z, Yardim S, Yurtlu S, Doğulu F, Kaymaz M, Paşaoğlu A. The effects of intravenous fentanyl and lidocaine infiltration on the hemodynamic response to skull pin placement. Neurosurg Rev 2001;24:35-37.

28. Murthy HS, Rao GS. Cardiovascular responses to scalp infiltration with different concentrations of epinephrine with or without lidocaine during craniotomy. Anesth Analg 2001;92:1516-519.

29. From RP, Warner DS, Todd MM, Sokoll MD. Anesthesia for craniotomy: a double-blind comparison of alfentanil, fentanyl, and sufentanil. Anesthesiology 1990;73:896-904.

30. Doblar DD, Lim YC, Baykan N, Frenette L. A comparison of alfentanil, esmolol, lidocaine, and thiopental sodium on the hemodynamic response to insertion of headrest skull pins. J Clin Anesth 1996;8:31-35.

31. Rubial M, Castells MV, Gargallo MC, Madrid JL. [Regional blockage for arterial blood pressure control during placement of head holder in neurosurgery]. Rev Esp Anestesiol Reanim 1992;39:282-284.

32. Matés JM, Pérez-Gómez C, Núñez de Castro I. Antioxidant enzymes and human diseases. Clin Biochem 1999;32: 595-603.

33. Vang O, Rasmussen BF, Andersen O. Combined effects of complex mixtures of potentially anti-carcinogenic compounds on antioxidant enzymes and carcinogen metabolizing enzymes in the rat. Cancer Lett 1997;114:283-286.

34. Young IS, Woodside JV. Antioxidants in health and disease. J Clin Pathol 2001;54:176-186.

35. Bae YS, Kang SW, Seo MS, Baines IC, Tekle E, Chock PB, Rhee SG. Epidermal growth factor (EGF)-induced generation of hydrogen peroxide. Role in EGF receptor-mediated tyrosine phosphorylation. J Biol Chem 1997;272:217-221.

36. Wojtaszek P. Oxidative burst: an early plant response to pathogen infection. Biochem J 1997;322:681-692.

37. Rikans LE, Hornbrook KR. Lipid peroxidation, antioxidant protection and aging. Biochim Biophys Acta 1997;1362: 116-127. 
38. Oesch F. Metabolism of carcinogens, possibilities for modulation. Acta Pharmacol Toxicol (Copenh) 1984;55: 15-33.

39. Meyer DF, Nealis AS, Macphee CH, Groot PH, Suckling KE, Bruckdorfer KR, Perkins SJ. Time-course studies by synchrotron X-ray solution scattering of the structure of human low-density lipoprotein during $\mathrm{Cu}(2+)$-induced oxidation in relation to changes in lipid composition. Biochem J 1996;319:217-227.

40. Aro HT, Markel MD, Chao EY. Cortical bone reactions at the interface of external fixation half-pins under different loading conditions. J Trauma 1993;35:776-785.

41. Briggs BT, Chao EY. The mechanical performance of the standard Hoffmann-Vidal external fixation apparatus. J Bone Joint Surg Am 1982;64:566-573.

42. Berg JO, Mössner BK, Skov MN, Lauridsen J, Gottrup F, Kolmos HJ. Antibacterial properties of EMLA and lidocaine in wound tissue biopsies for culturing. Wound Repair Regen 2006;14:581-585.

43. Johnson SM, Saint John BE, Dine AP. Local anesthetics as antimicrobial agents: a review. Surg Infect (Larchmt) 2008;9:205-213.

\section{Author Affiliations}

Ayse Mizrak, MD*; Ibrahim Erkutlu, MD广;

Mehmet Alptekin, MD广; Elzem Sen, MD*;

Murat Geyik, MD'; Abdulvahab Gok, MD';

Unsal Oner, $M D^{*}$

*Department of Anesthesiology and Reanimation,

Gaziantep University School of Medicine, Gaziantep, Turkey

tDepartment of Neurosurgery, Gaziantep University School

of Medicine, Gaziantep, Turkey 